Руденко П. А., кандидат ветеринарних наук

Луганський національний аграрний університет

\title{
ВИЗНАЧЕННЯ ЧУТЛИВОСТІ ДО АНТИМІКРОБНИХ ЗАСОБІВ ШТАМІВ МОЛОЧНОКИСЛИХ БАКТЕРІЙ, ІЗОЛЬОВАНИХ ВІД КЛІНІЧНО ЗДОРОВИХ КОТІВ
}

\section{Рецензент - доктор ветеринарних наук, професор В. Й. Іздепський}

\begin{abstract}
Доведено, щзо ізольовані культури виявили високу чутливість до антибіотиків групи $\beta$-лактамів (за винятком L. acidophilus №24, L. plantarum «Victoria» №22, L. rhamnosus №5, L. rhamnosus №20 i L. rhamnosus №26, які показали значну варіабельність чутливості до антибактеріальних препаратів наведеної групи, щзо свідчить про значний потенціал даних мікроорганізмів). Резистентність до аміноглікозидів, лінкозамидів і фторхінолонів (за винятком гатіфлоксацину, який показав високу ефективність по відношенню до всіх молочнокислих мікроорганізмів).
\end{abstract}

Ключові слова: антибіотики, молочнокислі бактерії, перспективні штами, коти.

Постановка проблеми. Порушення мікробіоценозів макроорганізму внаслідок широкого застосування антибіотиків спричинило появу у мікрофлори стійкості до них. Навіть раціональне застосування антибіотиків із дотриманням інструктивних даних щодо використання препарату створює надзвичайно важливу проблему: під дією пресингу антибіотиків у пацієнта змінюється якісний і кількісний склад його нормальної мікрофлори $[1,3,4]$. Особливо істотні зміни нормального біоценозу відбуваються в разі необгрунтованого, безконтрольного та тривалого застосування антибіотиків, а також за комбінованого лікування 3 використанням декількох препаратів [6, 9].

Аналіз основних досліджень і публікацій, у яких започатковано розв'язання проблеми. Визначення чутливості до антибіотиків перспективних штамів молочнокислих бактерій - важлива передумова для їх затвердження в якості пробіотика. За одночасного призначення 3 антибіотиками пробіотичних засобів, вони повинні бути стійкими до окремих антибактеріальних препаратів, аби вижити в шлунково-кишковому тракті $[5,7,10]$.

Метою нашої роботи стало з'ясування чутливості до ряду антибіотиків штамів біфідо- та лактобактерій, ізольованих 3 екологічних ніш організму клінічно здорових котів.

Завдання: провести визначення чутливості до антибіотиків групи $\beta$-лактамів; визначити резис- тентність до аміноглікозидів, лінкозамидів i фторхінолонів.

Матеріали і методи досліджень. Матеріалом для дослідження були 18 клінічно здорових котів, які знаходились у притулку для бездомних тварин ЗАТ «Ясинуватського машинобудівельного заводу» (м. Ясинувате Донецької області). Нами було віділено 37 (17,3 \%) штамів молочнокислих мікроорганізмів від загальної кількості вилучених культур.

Визначення чутливості біфідо- та лактофлори до антимікробних засобів проводили методом серійних розведень у живильному агарі [2]. В якості тест-препаратів використовували антибіотики, що широко використовуються у хірургічній практиці. Мінімальну інгибуючу концентрацію (МІК) протимікробного засобу визначали за затримкою росту мікроорганізмів у порівнянні 3 контролем на чашці, що містила найменшу кількість даного препарату. Для порівняння ефективності антибактеріальних засобів робили розрахунок $\mathrm{MIK}_{50}$ та $\mathrm{MIK}_{90}$ за допомогою пробіт-аналізу [8].

Результати досліджень. Доведено, що ізольовані культури B. bifidum проявляли найбільшу чутливість до препаратів групи $\beta$-лактамів (пеніцилінів та цефалоспоринів). Так, ріст чотирьох (100,0 \%) ізолятів B. bifidum концентрації бензилпеніциліну пригнічували у межах від 100 до 400; концентрації метіциліну - у межах від 62,5 до 500; концентрації амоксіцилліну - у межах від 12,5 до 25,0; концентрації цефазоліну - у межах від 12,5 до 50,0 ; концентрації цефтріаксону - у межах від 6,25 до 25,0 ; концентрації цефєпіму пригнічували у межах від 1,56 до 3,12 мкг/мл.

Високу ступінь резистентності виділених культур B. bifidum нами відмічено у відношенні до препарату групи аміноглікозидів - гентаміцину. Так, дози гентаміцину в діапазоні від 1,56 до 25,0 мкг/мл не діяли на дослідні ізоляти біфідобактерій; 100,0 \% штамів були резистентними до антибіотика. Проте концентрація препарату 50,0 мкг/мл пригнічувала ріст однієї $(25,0 \%)$, концентрація 100,0 мкг/мЛ двох (50,0 \%), а концентрація 200,0 мкг/мл - трьох 
(75,0 \%) дослідних культур B. bifidum. До того ж $\mathrm{MIK}_{50}$ гентаміцину до ізолятів $B$. bifidum становила 100,0 , а $\mathrm{MIK}_{90}-373,22$ мкг/мл.

Неоднорідну чутливість у виділених культур B. bifidum нами відмічено стосовно до антибіотика групи лінкозамидів - лінкоміцину. Так, дози препарату в діапазоні від 1,56 до 6,25 мкг/мл не діяли на дослідні штами, концентрація лінкоміцину 12,5 мкг/мл пригнічувала ріст однієї (25,0 \%), концентрація 50,0 мкг/мл пригнічувала ріст двух $(50,0 \%)$ і лише найбільше розведення антибіотика 100,0 мкг/мл пригнічувала ріст всіх чотирьох ізольованих культур біфідобактерій. До того ж МІК $_{50}$ лінкоміцину до ізолятів B. bifidum становила 60,99, а МІК ${ }_{90}$ - 786,22 мкг/мл.

Слід зауважити, що стійкою резистентністю дослідні штами $B$. bifidum володіли по відношенню до антимікробного засобу із групи фторированих хінолонів - енрофлоксацину. Так, концентрація препарату 6,25 мкг/мл пригнічувала ріст однієї $(25,0 \%)$, концентрація енрофлоксацину 12,5 та 25,0 мкг/мл пригнічувала ріст двох (50,0 \%), а до найменшого його розведення 50,0 мкг/мл чутливість проявляли три $(75,0$ \%) дослідні культури біфідобактерій. Проте ні один зі штамів B. bifidum не проявив стійкості до гатіфлоксацину - представника нового покоління фторхінолонів 3 антианаеробними властивостями (МІК 50 дорівнювало 0,12, a $\mathrm{MIK}_{90}-0,47$ мкг/мл).

Виділені нами від клінічно здорових котів штами $B$. adolescentis також проявляли найбільшу чутливість до антибіотиків групи $\beta$-лактамів. Так, концентрації бензилпеніциліну - від 200 до 400,0; амоксіцилліну - від 12,5 до 25,0 ; метіциліну - від 125,0 до 500,0; цефазоліну - від 12,5 до 50,0; цефтріаксону - від 6,25 до 25,0 ; цефєпіму - від 1,56 до 3,12 мкг/мл пригнічували ріст трьох (100,0 \%) дослідних культур біфідобактерій. Встановлено, що до дослідних ізолятів B. adolescentis гатіфлоксацин виявився також високоактивним засобом, МІК 50 препарату становила 0,19 , а МІК $90-1,57$ мкг/мл.

Необхідно зазначити, що неоднорідну чутливість ізоляти $B$. adolescentis проявляли до гентаміцину: всі дослідні штами були резистентними за концентрацій антибіотика в діапазоні від 1,56 до 12,5 мкг/мл, 2 (66,6 \%) ізоляти були стійкими за розведення препарату 25,0 і 50,0 мкг/мл і лише в мінімальному розведенні гентаміцину 200,0 мкг/мл усі три виділені культури $B$. adolescentis були до нього чутливі. МІК 50 гентаміцину дорівнювала 63,19, а МIК 90 - 492,38 мкг/мл.

Високу ступінь резистентності ізоляти $B$. adolescentis проявляли стосовно лінкоміцину: концен- трації антибіотика від 1,56 до 6,25 мкг/мл не діяли на дослідні штами, за розведень препарату 12,5 i 25,0 мкг/мл чутливість реєстрували в однієї (33,3 \%) дослідної культури, а максимальні концентрації лінкоміцину 50,0 і 100,0 мкг/мл були активні по відношенню до двох $(66,6$ \%) ізольованих культур біфідобактерій. До того ж MIК $_{50}$ антибіотика становила 35,35 , а МІК $90-459,68$ мкг/мл.

Нами встановлена також висока стійкість дослідних сапрофітних мікроорганізмів до енрофлоксацину: за максимальних розведень препарату від 0,78 до 6,25 мкг/мл ми реєструвари резистентність у трьох (100,0 \%) дослідних штамів; за розведення 12,5 мкг/мл стійкістю до енрофлоксацину володіли дві (66,6 \%) культури B. adolescentis, а за максимальних його концентрацій 25,0 і 50,0 мкг/мл нами виявлена чутливість у двох $(66,6 \%)$ культур біфідобактерій - MIК $_{50}$ енрофлоксацина становила 19,77, а МІК ${ }_{90}-154,27$ мкг/мл.

Дослідні штами лактобактерій проявляяють неоднорідну чутливість до антибіотиків групи $\beta$-лактамів. Так, ізоляти L. acidophilus виявилися чутливими до бензилпеніциліну (МIК 50 становила 31,89 , а МІК $_{90}-133,26$ мкг/мл), метіциліну $\left(\right.$ МІК $_{50}$ дорівнювала 39,86, а МІК ${ }_{90}-166,64$ мкг/мл), амоксіцилліну (МІК 50 1,99, а МIК ${ }_{90}-8,31$ мкг/мл), а також до цефепіму $\left(\mathrm{MIK}_{50}\right.$ препарату була 0,26, a $\mathrm{MIK}_{90}-1,29$ мкг/мл). Проте до антибіотиків цефалоспорінового ряду I і III поколінь цефазоліну та цефтріаксону відповідно ізольвані штами лактобактерій були резистентними. Так, навіть за максимальних концентрацій цефазоліну 25,0-50,0 i цефтріаксону 12,5-25,0 мкг/мл один $(9,1 \%)$ штам лактобактерій, а саме $L$. acidophilus №24, був стійким; $\mathrm{MIK}_{50}$ цефазоліну становила 12,60 , а $\mathrm{MIK}_{90}-$ 35,50 мкг/мл; МIК $_{50}$ цефтріаксону дорівнювала 2,54, а МІК 90 $_{\text {- }}$ 18,86 мкг/мл.

Зауважимо, що нами відмічено також високу ступінь резистентності у дослідних культур лактобактерій до гентаміцину, лінкоміцину та енрофлоксацину. Так, 100,0 \% дослідних штамів L. acidophilus були резистентними за концентрацій гентаміцину в діапазоні від 1,56 до 12,5 мкг/мл, 9 (81,8 \%) ізолятів були стійкими за розведення препарату 25,0 мкг/мл, 8 (72,7\%) мікроорганізмів проявляли резистентність до антибіотика при його розведенні 50,0 мкг/мл. Навіть за мінімального розведення гентаміцину 200,0 мкг/мл лише 6 (54,5\%) ізолятів L. acidophilus були чутливими до препарату. Концентрації лінкоміцину від 1,56 до 3,12 мкг/мл не діяли на дослідні штами; за розведень препарату 6,25 мкг/мл чутливість реєстрували у 4 (36,4 \%) виділених культур лактобактерій; за розведення 12,5 мкг/мл чутли- 
вими були $6(54,5 \%)$ ізолятів; за розведення 25,0 i 50,0 мкг/мл нами зареєстрований один $(9,1 \%)$ штам лактобактерій, а саме L. acidophilus №24, який був резистентним до препарату; лише за максимальної його концентрації 100,0 мкг/мл антибіотик проявляв ефективність до 100,0 \% дослідних бактерій. Встановлено, що за максимальних розведень енрофлоксацину в діапазоні 0,78-3,12 мкг/мл усі 11 (100,0 \%) ізолятів проявляли стійкість до препарату, навіть за мінімальних розведень антибіотика 25,0 і 50,0 мкг/мл 7 (63,6 \%) виділених культур L. acidophilus залишилися резистентними до нього. При цьому MIK $_{50}$ гентаміцину була 147,50 , а MIK $_{90}-$ 1796,29 мкг/мл; МІК 50 лінкоміцину дорівнювала 9,32, а МІК ${ }_{90}$ - 36,67 мкг/мл; МІК 50 енрофлоксацину становила 78,50, а МІК ${ }_{90}-1100,19$ мкг/мл.

Зазначимо, що до гатіфлоксацину, представника нового покоління фторированих хінолонів, ізольовані нами штами L. acidophilus проявляли чутливість. При цьому МIК 50 гатіфлоксацину дорівнювала 0,20 , а $\mathrm{MIK}_{90}-0,46$ мкг/мл.

Ізольовані штами L. plantarum проявляли неоднорідну чутливість до пеніцилінів. Так, дослідні культури були чутливі до метіциліну - концернтрації антибіотика в діапазоні від 125,0 до 500,0 мкг/мл затримували ріст дев'яти (100,0 \%) виділених бактерій. До бензилпеніциліну в концернтрації 200,0 мкг/мл залишився стійким один (11,1 \%) штам лактобактерій, а саме L. plantarum «Victoria» №22, проте за найбільшого розведення антибіотика 400,0 мкг/мл всі 9 (100,0 \%) дослідних ізолятів були до нього чутливими. До амоксіцилліну, навіть у його максимальній концентрації 25,0 мкг/мл, встановлена стійкість у одного (11,1\%) ізоляту, а саме у L. plantarum «Victoria» №22.

Нами також встановлено неоднорідну чутливість у дослідних культур лактобактерій до цефалоспоринів. Так, концентрації цефазоліну в діапазоні від 0,78 до 3,12 мкг/мл не діяли на всі ізольовані штами; за розведення препарату 6,25 мкг/мл стійкість виявлена у 7 (77,8 \%) культур лактобактерій; за концентрації антибіотика 12,5 мкг/мл чутливими до нього були 5 (55,5 \%) ізолятів; за його розведення 25,0 мкг/мл чутливість виявлена у шести $(66,7$ \%) мікроорганізмів; навіть у максимальній його концентрації 50,0 мкг/мл виявлена резистентність до цефазоліну у однієї $(11,1 \%)$ виділеної культури L. plantarum, а саме у L. plantarum «Victoria» №22. Необхідно відмітити, що штам L. plantarum «Victoria» №22 проявляв стійкість до цефтріаксону i цефєпіму у концентраціях 12,5 i
1,56 мкг/мл відповідно. Проте найменші розведення цефтріаксону 25,0 і цефєпіму 3,12 мкг/мл затримували ріст усіх дев'яти (100,0 \%) ізолятів лактобактерій. При цьому $\mathrm{MIK}_{50}$ цефазоліну становила 13,9, а МIК ну дорівнювала 5,46, а МІК 90 - 13,45 мкг/мл; МІК 50 цефєпіму складала 0,68 , а МIК 90 - 1,67 мкг/мл.

Доведено, що у дослідних культур L. plantarum спостерігається резистентність до лінкоміцину: навіть за максимальних концентрацій антибіотика 50,0 і 100,0 мкг/мл нами виявлена стійкість у одного $(11,1 \%)$ ізоляту, а саме у L. plantarum «Victoria» №22. При цьому МІК 50 лінкоміцину становила 13,79, а МІК ${ }_{90}$ - 67,54 мкг/мл. Нами встановлена також висока ступінь резистентності у дослідних ізолятів лактобактерій до гентаміцину та енрофлоксацину. Так, концентрації гентаміцину в діапазоні від 1,56 до 12,5 мкг/мл не затримували ріст дев'яти (100,0 \%) ізольованих культур мікроорганізмів; за розведення 25,0 мкг/мл - спостерігали стійкість у восьми $(88,9 \%)$ штамів; за концентрацій 50,0 і 100,0 мкг/мл чутливість спостерігали у чотирьох $(44,4 \%)$ ізолятів; навіть за мінімального розведення антибіотика 200,0 мкг/мл нами виявлена резистентність у чотирьох $(44,4 \%)$ виділених культур L. plantarum. Максимальні концентрації енрофлоксацину 25,0 і 50,0 мкг/мл затримували ріст п'яти $(55,5 \%)$ ізольованих штамів мікроорганізмів. При цьому МІК $_{50}$ гентаміцину становила 126,15 , а $\mathrm{MIK}_{90}$ - 1383,31 мкг/мл; МІК $_{50}$ енрофлоксацину дорівнювала 54,87, а МІК ${ }_{90}-1048,11$ мкг/мл. Необхідно звернути увагу й на те, що нами встановлена висока чутливість у ізолятів L. plantarum до гатіфлоксацину: $\mathrm{MIK}_{50}$ гатіфлоксацину дорівнювала 0,13 , а $\mathrm{MIK}_{90}-0,35$ мкг/мл. Усі ізоляти L. rhamnosus були чутливими до бензилпеніциліну (MIK $_{50}$ антибіотика дорівнювала 55,3, а МIK 90 204,77 мкг/мл), цефтріаксону (МІК 50 препарату складала 3,12, а МІК 90 - 8,98 мкг/мл) і гатіфлоксацину $\left(\mathrm{MIK}_{50}\right.$ фторхінолону дорівнювала 0,24 , а $\mathrm{MIK}_{90}-0,73$ мкг/мл). Неоднорідну чутливість ізольовані штами лактобактерій проявяли до цефєпіму. Так, концентрації цефєпіму в діапазоні від 0,04 до 0,18 мкг/мл не затримували ріст усіх десяти ізольованих культур бактерій; за розведення 0,39 мкг/мл ми спостерігали чутливість у трьох (30,0 \%) ізолятів; за концентрації 0,78 мкг/мл чутливість спостерігали у семи $(70,0 \%)$ виділених мікроорганізмів; за концентрації 1,56 мкг/мл встановлена стійкість до антибіотика лише у одного (10,0\%) штаму, а саме у L. rhamnosus №26; однак усі 10 $(100,0 \%)$ дослідних лактобактерій були чутливими до цефалоспоріну IV покоління за його мінімального розведення 3,12 мкг/мл. При цьому $\mathrm{MIK}_{50}$ 
цефєпіму складала 0,56 , а $\mathrm{MIK}_{90}$ - 1,47 мкг/мл.

Встановлено, що у дослідних ізолятів L. rhamnosus існує стійкість до цефазоліну: навіть за максимальної концентрації антибіотика 50,0 мкг/мл ми спостерігали резистентність до нього у двох (20,0\%) ізольованих штамів, а саме у L. rhamnosus №5 i L. rhamnosus №26. При цьому $\mathrm{MIK}_{50}$ цефазоліну дорівнювала 14,75 , а $\mathrm{MIK}_{90}-$ 72,47 мкг/мл. Окрім того, резистентність у лактобактерій зареєстровано і до амоксіциліну. Так, за мінімальних розведень антибіотика 12,5 i 25,0 мкг/мл стійкість спостерігали також у двох (20,0 \%) дослідних ізолятів, а саме у L. rhamnosus №20 i L. rhamnosus №26. При цьому $\mathrm{MIK}_{50}$ амоксіциліну складала 6,80 , а МІК ${ }_{90}-30,26$ мкг/мл. Високу ступінь резистентності ми реєстрували у дослідних штамів мікроорганізмів також до метіциліну, гентаміцину, лінкоміцину та енрофлоксацину. Навіть за максимальних концентрацій метіциліну 250,0 і 500,0 мкг/мл стійкістю до нього володіли три $(30,0 \%)$ штами, а саме L. rhamnosus №5, L. rhamnosus №20 i L. rhamnosus №26. При цьому МІК 139,47 , а МІК ${ }_{90}-1455,76$ мкг/мл. За мінімального розведення гентаміцину 200,0 мкг/мл лише 5 (50,0 \%) дослідних культур лактобактерій були чутливими до препарату. При цьому $\mathrm{MIK}_{50}$ гентаміцину складала 179,89 , а МІК ${ }_{90}-1372,70$ мкг/мл. За максимальних концентрацій лінкоміцину

\section{БІБЛІОГРАФІЯ}

1. Раціональне використання антимікробних препаратів як фактор стимулювання розвитку антибіотикорезистентності / М. Косенко, В. Музика, Ю. Косенко [та ін.] // Ветеринарна медицина України. - 2007. - №8. - С. 40-41.

2. Руководство к лабораторным занятиям по микробиологии / Л. Б. Борисов, . И. КузьминСоколов, И. С. Фрейлин [и др.] / Под ред. Л. Б. Борисова. - 2-е изд., перераб. и доп. - М. : Медицина, 1984. - С. 77-78.

3. Сотніков В. Сучасна антибіотикотерапія у ветеринарії / В. Сотніков // Ветеринарна практика. - 2008. - №5. - С. 14.

4. Шкиль Н. Н. Изменение антибиотикочувствительности микроорганизмов при контакте с антибактериальными препаратами / Н. Н. Шкиль, Ю. В. Конюхова, Н. А. Шкиль // Ветеринарный врач. - 2008. - №3. - С. 33-35.

5. Antibiotic susceptibility of different lactic acid bacteria strains / N. Karapetkov, R. Georgieva, N. Rumyan [et al.] // Benef. Microbes. - 2011.№ 2(4). - P. 335-339.

6. Condition-based use of antimicrobials in cats in
50,0 і 100,0 мкг/мл стійкість зареєстровано у шести $(60,0 \%)$ ізольованих культур L. rhamnosus. При цьому МIК 50 лінкоміцину дорівнювала 179,89 , а МІК $_{90}$ - 1372,70 мкг/мл. Максимальна концентрація енрофлоксацину 50,0 мкг/мл також не діяла на шість $(60,0$ \%) ізолятів дослідних мікроорганізмів. При цьому МIК 50 енрофлоксацину складала 89,71, а МІК 90 - 1867,97 мкг/мл.

Висновки: 1. Ізольовані нами культури біфідо- і лактобактерій виявили високу чутливість до антибіотиків групи $\beta$-лактамів (за винятком L. acidophilus №24, L. plantarum «Victoria» №22, L. rhamnosus №5, L. rhamnosus №20 i L. rhamnosus №26, які показали значну варіабельність чутливості до антибактеріальних препаратів даної групи, що свідчить про значний потенціал цих мікроорганізмів), резистентність до аміноглікозидів, лінкозамидів і фторхінолонів (за винятком гатіфлоксацину, що показав високу ефективність по відношенню до всіх молочнокислих мікроорганізмів).

2. Отримані відмінності в антибіотикорезистентності перспективних штамів лактобактерій доводять перевагу створення комплексних пробіотичних препаратів.

У наступних дослідженнях необхідно встановити адгезивні та антагоністичні властивості культур-кандидатів у пробіотичні препарати для лікування та профілактики хірургічної інфекції в котів.

Finland: results from two surveys / K. H. Thomson, M. H. Rantala, T. K. Viita-Aho [et al.] // J. Feline Med. Surg. - 2009. - №11(6). - P. 462-466.

7. Characterization of vaginal lactobacilli in women after kidney transplantation / G. Martirosian, H. Radosz-Komoniewska, B. Pietrzak [et al.] // Anaerobe. - 2012. - № 18(2). - P. 209-213.

8. In vitro activity of tigecycline, a new glycylcycline, tested against 1326 clinical bacterial strains isolated from Latin America / A. C. Gales, R. N. Jones, S. S. Andrade [et al.] // The Brazilian J. of Infect. Dis. - 2005. - Vol. 9(5). - P. 348-356.

9. Severe abdominal dog bite wounds in a pregnant cat / I. H. Kumru, K. Seyrek-Intas, B. Tuna [et al.] // J. Feline Med. Surg. - 2007. - №3. - P. 499-502.

10. The natural antimicrobial peptide subtilosin acts synergistically with glycerol monolaurate, lauric arginate, and $\varepsilon$-poly-L-lysine against bacterial vaginosisassociated pathogens but not human lactobacilli / K. S. Noll, M. N. Prichard, A. Khaykin [et al.] // Antimicrob. Agents Chemother. - 2012. - № 56(4). P. 756-761. 